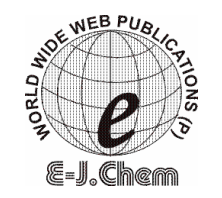

http://www.e-journals.net
ISSN: 0973-4945; CODEN ECJHAO

E-Journal of Chemistry

Vol. 5, No. 1, pp. 16-22, January 2008

\title{
Impact of Tsunami on the Heavy Metal Accumulation in Water, Sediments and Fish at Poompuhar Coast, Southeast Coast of India
}

\author{
P. MARTIN DEVA PRASATH* ${ }^{*}$ and T. HIDAYATHULLA KHAN \\ *Department of Chemistry, TBML College, Porayar - 609 307, Tamil Nadu, India \\ Department of Chemistry, Khadir Mohideen College, Adiramapattinam - 614 701, India \\ martinprasath@rediffmail.com
}

Received 13 July 2007; Accepted 25 August 2007

\begin{abstract}
Investigations on the accumulation of heavy metals ( $\mathrm{Zn}, \mathrm{Cu}, \mathrm{Fe}$, $\mathrm{Mn}, \mathrm{Co}, \mathrm{Pb}, \mathrm{Cd}$ and $\mathrm{Ni}$ ) in water, sediments and fish (Mugil cephalus) using Atomic Absorption Spectrophotometer at Poompuhar coast, lying along the southeast coast of India was studied before and after tsunami. Accumulation of heavy metals was observed in the order of Sediments $>$ Fish $>$ Water. In water, the order was found to be $\mathrm{Mn}>\mathrm{Fe}>\mathrm{Zn}>\mathrm{Cu}>\mathrm{Ni}>\mathrm{Cd}>\mathrm{Co}>\mathrm{Pb}$; $\mathrm{Mn}$ recorded a maximum of $506.9 \mu . \mathrm{L}^{-1}$ and $\mathrm{Pb}$ recorded a minimum of $0.006 \mu . \mathrm{L}^{-1}$. In sediments, the order was $\mathrm{Mn}>\mathrm{Fe}>\mathrm{Cu}>\mathrm{Zn}>\mathrm{Pb} \approx \mathrm{Co} \approx \mathrm{Cd} \approx \mathrm{Ni}$; $\mathrm{Mn}$ recorded a maximum of $851.1 \mu \mathrm{g} . \mathrm{g}^{-1}$ and a minimum of below detectable levels were found in $\mathrm{Pb}, \mathrm{Co}, \mathrm{Cd}$ and $\mathrm{Ni}$. In fish, the order was found to be $\mathrm{Fe}>\mathrm{Zn}>$ $\mathrm{Mn}>\mathrm{Cu}>\mathrm{Ni}>\mathrm{Co} \approx \mathrm{Pb} \approx \mathrm{Cd} ; \mathrm{Fe}$ recorded a maximum of $529.13 \mu \mathrm{g} . \mathrm{g}^{-1}$ and a minimum of below detectable levels were found in $\mathrm{Pb}$ and $\mathrm{Cd}$.
\end{abstract}

Keywords: Tsunami, Fish, Water, Sediment, Heavy metals, Poompuhar.

\section{Introduction}

Marine ecosystems are highly complex, dynamic and subject to many internal and external relationships that are subject to change over time. The pollutants that enter the inshore waters and estuaries create serious problems causing extensive damage to the life and activities of the living aquatic organisms and even to mass mortality ${ }^{1}$. Among the pollutants, accumulation of heavy metals in marine ecosystems is of global importance. Significant contributions have been made with reference to oceanic and coastal distribution of various heavy metals ${ }^{2}$. The heavy metals generally, enter the aquatic environment through atmospheric deposition, erosion of geological matrix or due to anthropogenic activities caused by industrial effluents, domestic sewage and mining wastes, ${ }^{3,4}$. The metal contaminants in aquatic systems usually remain either in soluble or suspension form and finally tend to settle down to the bottom are taken up by the organisms. The progressive and irreversible accumulation of these metals in various organs of marine creatures leads to 
metal related diseases in the long run because of their toxicity, thereby endangering the aquatic biota and other organisms ${ }^{5,6}$. Fishes being one of the main aquatic organisms in the food chain may often accumulate large amounts of certain metals ${ }^{7,8}$. Directly acting or synergistically acting metals like $\mathrm{Fe}, \mathrm{Zn}, \mathrm{Pb}, \mathrm{Cd}, \mathrm{Cu}$ and $\mathrm{Mn}$ are common toxic pollutants for fish ${ }^{9}$. Normally, fishes assimilate these heavy metals through ingestion of suspended particulates, food materials and / or by constant ion-exchange process of dissolved metals across lipophilic membranes like the gills / adsorption of dissolved metals on tissue and membrane surfaces. Further, the tsunami that struck the Indian coasts on $26^{\text {th }}$ December 2004 with the speed of more than $700 \mathrm{~km} / \mathrm{hr}$ has caused considerable changes in the marine eco system by polluting the marine environment with high turbidity and also breaking the coastal vegetations ${ }^{10}$. With this view, the present study is aimed to determine the impact of tsunami on the accumulation of heavy metals in water, sediment and fishes - Mugil cephalus in Poompuhar coast of the Bay of Bengal, southeast coast of India and to compare these values with pre tsunami data.

\section{Description of the Study Area}

The study area was Poompuhar, a coastal town station [lat. $11^{\circ} 6^{`} \mathrm{~N}$; Long. $80^{\circ} 4^{`} \mathrm{E}$ ] one of the severely affected station of the $26^{\text {th }}$ December 2004 tsunami in Nagapattinam district of Tamil Nadu located along the south east coast of India

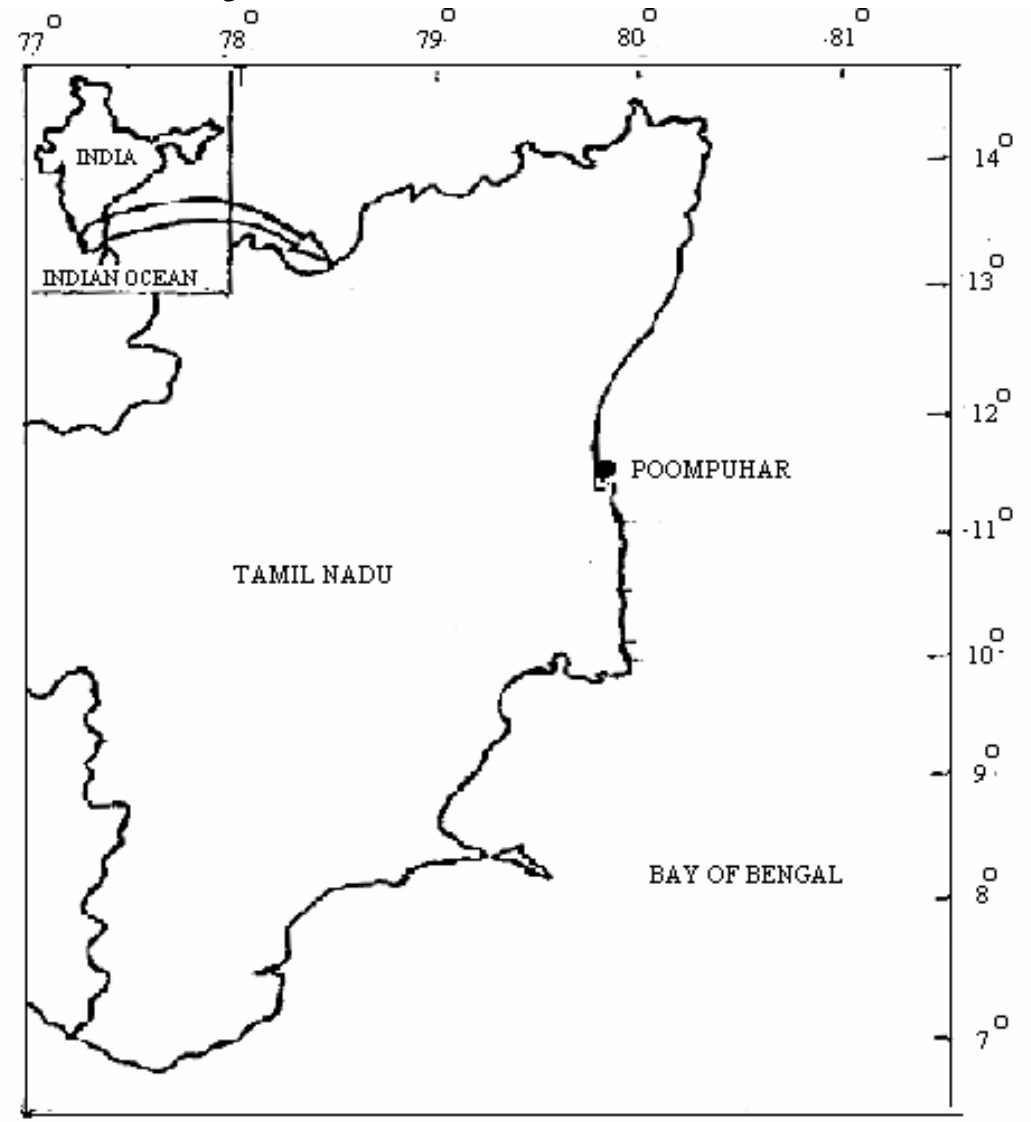

Figure 1. Study area. 


\section{Experimental}

Water samples, sediments and fish samples were collected in Poompuhar coast in Nagapattinam district of Tamil Nadu, India on $28^{\text {th }}$ November 2004 [Pre tsunami] and on $26^{\text {th }}$ January 2005 [Post tsunami] and were analyzed. Poompuhar coast receives domestic and municipal sewages; shrimp farm effluents and agricultural discharges mainly through Uppanar estuary.

Surface water samples were collected in pre cleaned and acid washed polypropylene bottles and they were filtered in Millipore filter paper [mesh size $0.45 \mu$ ]. The samples were preconcentrated with APDC - MIBK extraction procedure ${ }^{11}$. The resulting solution was aspirated to the flame Atomic Absorption Spectrophotometer [Perkin - Elmer Model 373] for the determination of $\mathrm{Zn}, \mathrm{Cu}, \mathrm{Fe}, \mathrm{Mn}, \mathrm{Co}, \mathrm{Pb}, \mathrm{Cd}$ and $\mathrm{Ni}$.

Sediment samples were collected in pre cleaned, acid washed PVC corer, transferred to clean poly bags and transported to the laboratory. These samples were then washed with metal free double distilled water and dried in hot air oven at $110^{\circ} \mathrm{C}$ for 5 to 6 hours and ground to powder in a glass mortar and stored in pre cleaned polythene bags. $500 \mathrm{mg}$ of the sample was taken and digested with a mixture of $1 \mathrm{~mL}$ of con. $\mathrm{H}_{2} \mathrm{SO}_{4}, 5 \mathrm{~mL}$ of con. $\mathrm{HNO}_{3}$ and $2 \mathrm{~mL}$ of $\mathrm{HClO}_{4}$. A few drops of $\mathrm{HF}$ was added to achieve complete digestion and the sample was filtered and made up to $25 \mathrm{~mL}$ with metal free double distilled water for the estimation of $\mathrm{Zn}$, $\mathrm{Cu}, \mathrm{Fe}, \mathrm{Mn}, \mathrm{Co}, \mathrm{Pb}, \mathrm{Cd}$ and $\mathrm{Ni}$ using flame atomic absorption spectrophotometer ${ }^{12}$.

Fresh specimens of fish Mugil cephalus were washed and collected from the study area before and after tsunami (i.e. on $28^{\text {th }}$ November 2004 and $26^{\text {th }}$ January 2005) by cast net and gill net operation. The fish samples (90-270mm total length) were washed and dissected using a stainless steel scalpel and the body muscle below the first dorsal fin was removed for the analysis of $\mathrm{Zn}, \mathrm{Cu}, \mathrm{Fe}, \mathrm{Mn}, \mathrm{Co}, \mathrm{Pb}, \mathrm{Cd}$ and $\mathrm{Ni}$ by standard method ${ }^{13}$. The dissected portion of body muscle tissues was dried in an oven at $110^{\circ} \mathrm{C}$ for $24 \mathrm{~h}$. It was then weighed and subjected to acid digestion with $3: 1 \mathrm{~mL}$ of conc. $\mathrm{HNO}_{3}$ and $\mathrm{HClO}_{4}$ on a hot plate until a clear solution was obtained. The digested samples were then made up to $25 \mathrm{~mL}$ with metal free doubled distilled water and analyzed for the above mentioned methods using Atomic Absorption Spectrophotometer.

\section{Results and Discussion}

Variation in the accumulation of $\mathrm{Zn}, \mathrm{Cu}, \mathrm{Fe}, \mathrm{Mn}, \mathrm{Co}, \mathrm{Pb}, \mathrm{Cd}$ and $\mathrm{Ni}$ in water, sediments and Mugil Cephalus recorded at Poompuhar coast before and after tsunami are shown in Figures 2 to 4 and the values of heavy metals observed before and after tsunami in the three samples are given in Tables 1 to 3 .

Table 1. Heavy metal concentration $\left(\mu \mathrm{g} . \mathrm{L}^{-1}\right)$ recorded in water samples of Poompuhar coast, before and after Tsunami.

\begin{tabular}{cccc}
\hline S.No. & Heavy Metals, $\mu \mathrm{g} . \mathrm{L}^{-1}$ & Before Tsunami & After Tsunami \\
\hline 1 & $\mathrm{Zn}$ & 49.66 & 54.25 \\
2 & $\mathrm{Cu}$ & 13.01 & 15.65 \\
3 & $\mathrm{Fe}$ & 307.7 & 325.9 \\
4 & $\mathrm{Mn}$ & 506.9 & 489.5 \\
5 & $\mathrm{Co}$ & 0.04 & 0.07 \\
6 & $\mathrm{~Pb}$ & 0.006 & 0.009 \\
7 & $\mathrm{Cd}$ & 0.06 & 0.08 \\
8 & $\mathrm{Ni}$ & 0.16 & 0.24 \\
\hline
\end{tabular}


In water, the accumulation of heavy metals was observed in the order of $\mathrm{Mn}>\mathrm{Fe}>$ $\mathrm{Zn}>\mathrm{Cu}>\mathrm{Ni}>\mathrm{Cd}>\mathrm{Co}>\mathrm{Pb}$. Highest recorded value among heavy metals was $\mathrm{Mn}$ which varied from $489.5 \mu \mathrm{g} . \mathrm{L}^{-1}$ to $506.9 \mu \mathrm{g} . \mathrm{L}^{-1}$ and the lowest recorded value among heavy metals was $\mathrm{Pb}$ which varied from $0.04 \mu \mathrm{g} . \mathrm{L}^{-1}$ to $0.07 \mu \mathrm{g} . \mathrm{L}^{-1}$. Except $\mathrm{Mn}$ all the other metals $(\mathrm{Zn}, \mathrm{Cu}, \mathrm{Fe}, \mathrm{Co}, \mathrm{Pb}, \mathrm{Cd}$ and $\mathrm{Ni}$ ) recorded higher concentrations after the tsunami. This variation in metal concentrations is due to the presence of major sources of metal pollution, intensive human activity and discharge of municipal waste and industrial effluents $^{2}$. Also, the variation in the metal concentration is due to the impact of tsunami that caused large scale seawater inundation and the receding tidal waves carried into the sea, debris, anthropogenic wastes, adjacent terrestrial parts including plastic materials and domestic disposals from the near lands ${ }^{14}$.

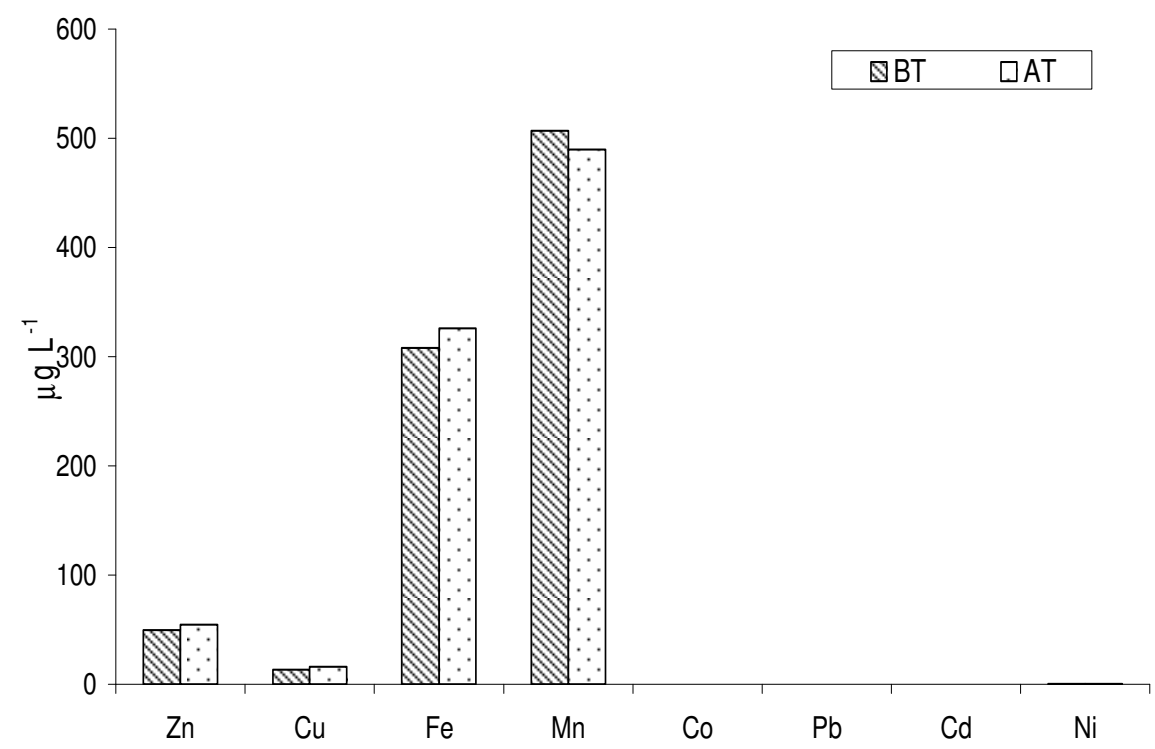

Figure 2. Heavy Metal Concentrations $\left(\mu \mathrm{g} . \mathrm{L}^{-1}\right)$ recorded in Water Samples of Poompuhar coast, before and after Tsunami

Table 2. Heavy metal concentration $\left(\mu \mathrm{g} \cdot \mathrm{g}^{-1}\right)$ recorded in sediment samples of Poompuhar coast, before and after Tsunami

\begin{tabular}{cccc}
\hline S.No. & Heavy Metals, $\mu \mathrm{g} . \mathrm{g}^{-1}$ & Before Tsunami & After Tsunami \\
\hline 1 & $\mathrm{Zn}$ & 5.9 & 7.3 \\
2 & $\mathrm{Cu}$ & 31.4 & 47.9 \\
3 & $\mathrm{Fe}$ & 257.4 & 145.6 \\
4 & $\mathrm{Mn}$ & 851.1 & 771.6 \\
5 & $\mathrm{Co}$ & $\mathrm{ND}$ & $\mathrm{ND}$ \\
6 & $\mathrm{~Pb}$ & $\mathrm{ND}$ & $\mathrm{ND}$ \\
7 & $\mathrm{Cd}$ & $\mathrm{ND}$ & $\mathrm{ND}$ \\
8 & $\mathrm{Ni}$ & $\mathrm{ND}$ & $\mathrm{ND}$ \\
\hline
\end{tabular}


In sediments, the accumulation of heavy metals was found in the order of $\mathrm{Mn}>\mathrm{Fe}>\mathrm{Cu}$ $>\mathrm{Zn}>\mathrm{Pb}>\mathrm{Co} \approx \mathrm{Cd} \approx \mathrm{Ni}$. $\mathrm{Zn}$ and $\mathrm{Cu}$ recorded higher values whereas $\mathrm{Fe}$ and $\mathrm{Mn}$ recorded lower values after tsunami. Highest recorded value among heavy metals was Mn which varied from $771.6 \mu \mathrm{g} . \mathrm{g}^{-1}$ to $851.1 \mu \mathrm{g} . \mathrm{g}^{-1}$. Undetectable concentrations were found in the metals $\mathrm{Pb}, \mathrm{Co}, \mathrm{Cd}$ and $\mathrm{Ni}$. This variation in heavy metal concentration was due to the continuous stirring of sediments by the high speed of tsunami tidal actions.

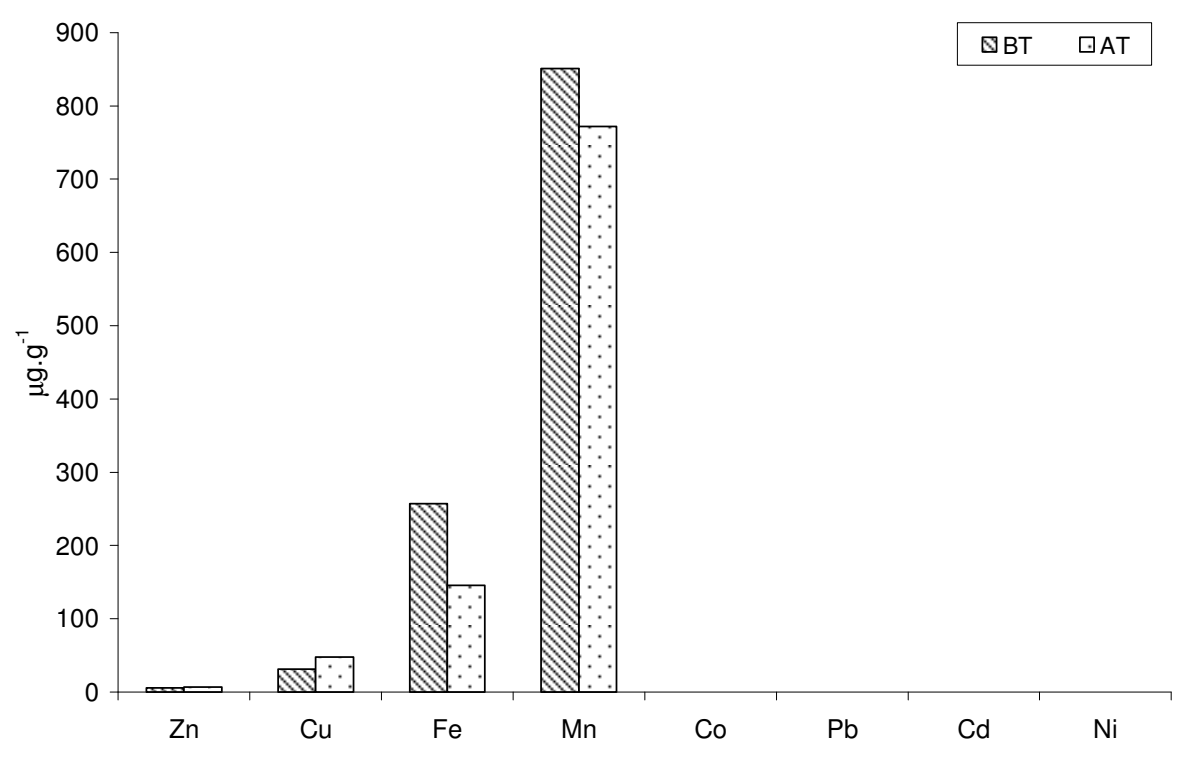

Figure 3. Heavy Metal Concentrations $\left(\mu \mathrm{g} . \mathrm{g}^{-1}\right)$ recorded in Sediment samples of Poompuhar coast, before and after Tsunami.

Table 3. Heavy metal concentration $\left(\mu \mathrm{g} \cdot \mathrm{g}^{-1}\right)$ recorded in fish samples of Poompuhar coast, before and after Tsunami

\begin{tabular}{cccc}
\hline S.No. & Heavy Metals, $\mu \mathrm{g} . \mathrm{g}^{-1}$ & Before Tsunami & After Tsunami \\
\hline 1 & $\mathrm{Zn}$ & 142.11 & 156.78 \\
2 & $\mathrm{Cu}$ & 14.4 & 20.48 \\
3 & $\mathrm{Fe}$ & 479.0 & 529.13 \\
4 & $\mathrm{Mn}$ & 18.43 & 25.48 \\
5 & $\mathrm{Co}$ & 0.001 & 0.001 \\
6 & $\mathrm{~Pb}$ & $\mathrm{ND}$ & $\mathrm{ND}$ \\
7 & $\mathrm{Cd}$ & $\mathrm{ND}$ & $\mathrm{ND}$ \\
8 & $\mathrm{Ni}$ & 0.003 & 0.004 \\
\hline
\end{tabular}

In fish samples, the accumulation of heavy metals was found in the order of $\mathrm{Fe}>\mathrm{Zn}>$ $\mathrm{Mn}>\mathrm{Cu}>\mathrm{Ni}>\mathrm{Co} \approx \mathrm{Pb} \approx \mathrm{Cd}$. Like water, in fish samples $\mathrm{Zn}, \mathrm{Cu}, \mathrm{Fe}, \mathrm{Mn}$, and Ni recorded higher values after tsunami. The highest recorded value among heavy metals was $\mathrm{Fe}$ which varied from $479.0 \mu \mathrm{g} \cdot \mathrm{g}^{-1}$ to $529.13 \mu \mathrm{g} \cdot \mathrm{g}^{-1}$. Undetectable levels were found in $\mathrm{Pb}$ and $\mathrm{Cd}$ and no variation was found in Co. 


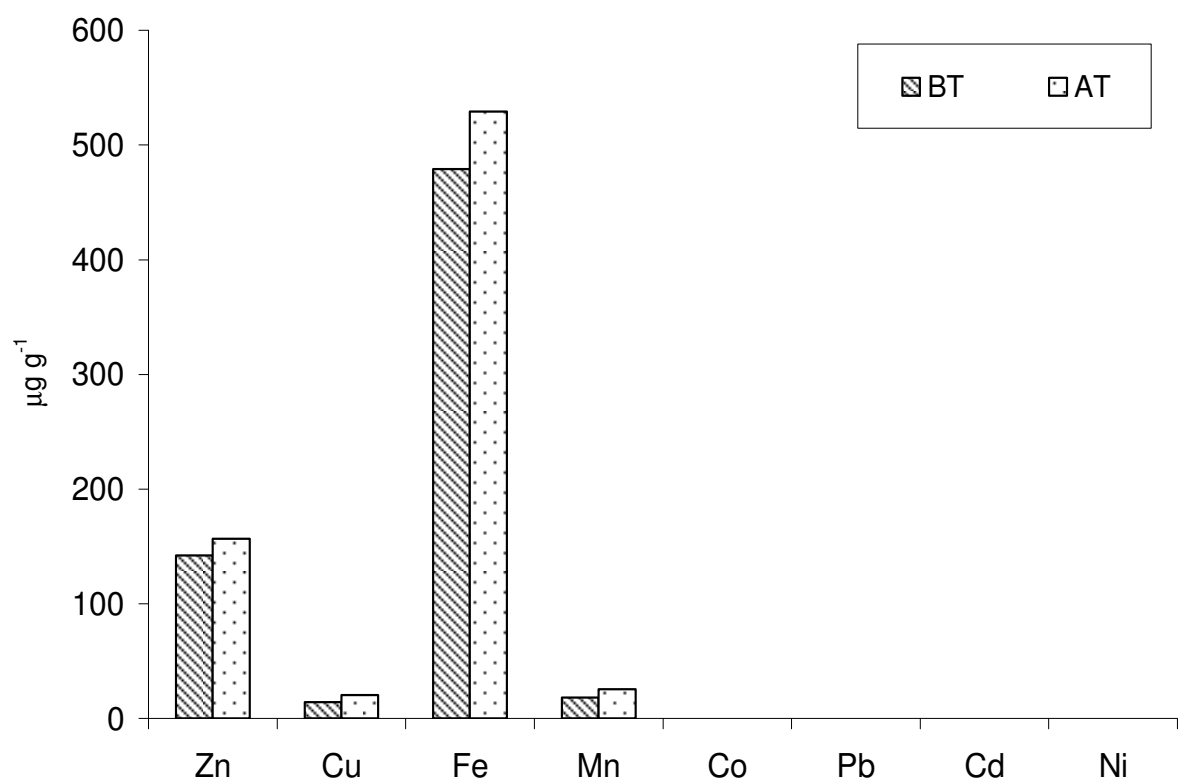

Figure 4. Heavy Metal Concentrations $\left(\mu \mathrm{g} \cdot \mathrm{g}^{-1}\right)$ recorded in Fish samples of Poompuhar coast, before and after Tsunami

\section{Conclusion}

In general, the present study clearly showed significant variations in the accumulation of heavy metals in water, sediments and fish Mugil Cephalus after tsunami. These variations in the marine environment are certainly brought about by the recent tsunami as similar type of variations in the physico chemical characters were observed in the coastal water quality off Nagapattinam coasts ${ }^{15}$. Many of the earlier works revealed that heavy metals were more concentrated in the tissues of marine animals than in seawater due to bio magnification ${ }^{16-18}$. The same trend was observed in the present study also. It may also be expected that the high concentration of metals in water can be gradually accumulated on the sediments and in due course it may get transferred to fish. When monthly and seasonal monitoring of heavy metals is done using finfish and shellfish as monitors, the exact effect of tsunami in this area can be ascertained.

\section{References}

1 Ananthan G, Plankton Ecology and Heavy Metal Studies in the Marine Environs of Pondicherry, India. Ph.D Thesis. Annamalai University, Annamalainagar, India, 1994.

2 Govindasamy C and J Azariah, Indian. J. Mar. Sci., 1999, 28: 249-256.

3 Gumgum B, Unlu E, Tez Z and Gulsun Z, Chemosphere, 1994, 29,111-116.

4 Alam M G M., Tanaka A, Allinson G, Lawrenson L J B, Stagnitti F and Snow E T, Jpn. Ecotoxicol. Environ. Safety, 2002, 53, 348-354.

5 Watling H R, Bull. Environ. Contam. Toxicol., 1983, 30, 213-320.

6 Melville F and Burchett M, Mar. Pollut. Bull., 2002, 44, 469 - 479.

7 Mansour S A. and Sidky M, Food Chem., 2002, 78, 15-22. 
8 Hadson P V, Aquat. Toxicol., 1988, 11, 3-18.

9 Srivastava C B I, A Textbook of Fishery Science and Indian Fisheries, Kitamahal Publications, Allahabad, India, 1985, pp307.

10 Kannan L, Thangaradjou T and Duraisamy A, Effects of Tsunami on the Coastal and Marine Biodiversity of India, Proceedings of the brain storming session on "Tsunami Mitigation Strategies" held at Bharathidasan University, India, 25-26 ${ }^{\text {th }}$ February, 2005,.

11 Brooks R R, Presley B J and Kalplan I R, Talanta, 1967, 14, 809-816.

12 Chester R and Hughes M J, Chem.Geol., 1967, 2, 249-263.

13 Topping G, Aquaculture, 1973, 1, 373-377.

14 Martin Deva Prasath P, Palanisamy M and Kunjitham R, J. Curr. Sci., 2006, 9 (2):713-716.

15 Martin Deva Prasath P, Hidiyathullakhan $\mathrm{T}$ and Sankar K, Journal of Applied Geochemistry, 2007, 9(1),135-141.

16 Martin Deva Prasath P, Vijayakumar R and Kulathooran S, The Ekologia, 2006, 5 (1-2), 75-80.

17 Leatherland P M, Burton J D, Culkin F, McCartney M J and Morris R J, Deep Sea Res., 1973, 20: 679-685.

18 Klein D and Goldberg E D, Environ. Sci. Technol., 1970, 4: 765-768. 


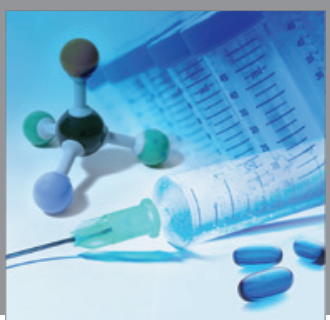

International Journal of

Medicinal Chemistry

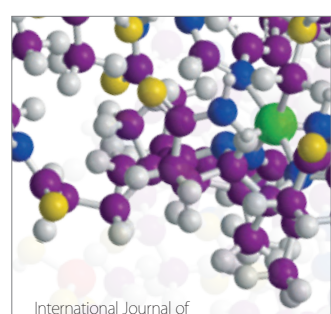

Carbohydrate Chemistry

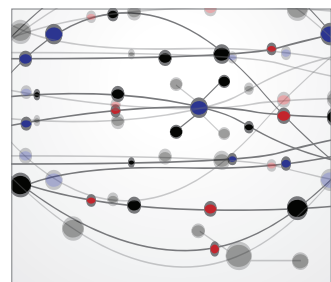

The Scientific World Journal
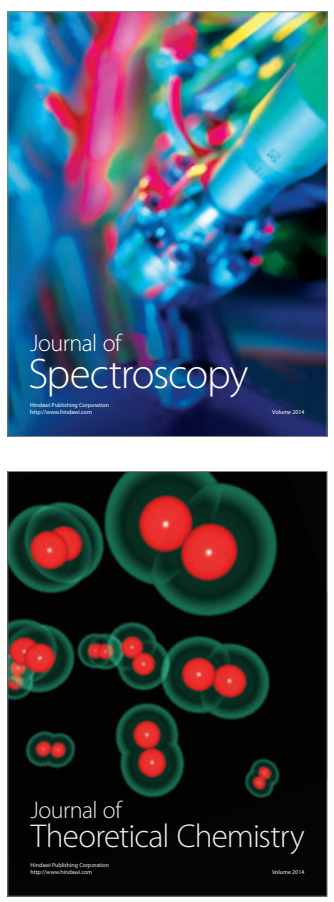
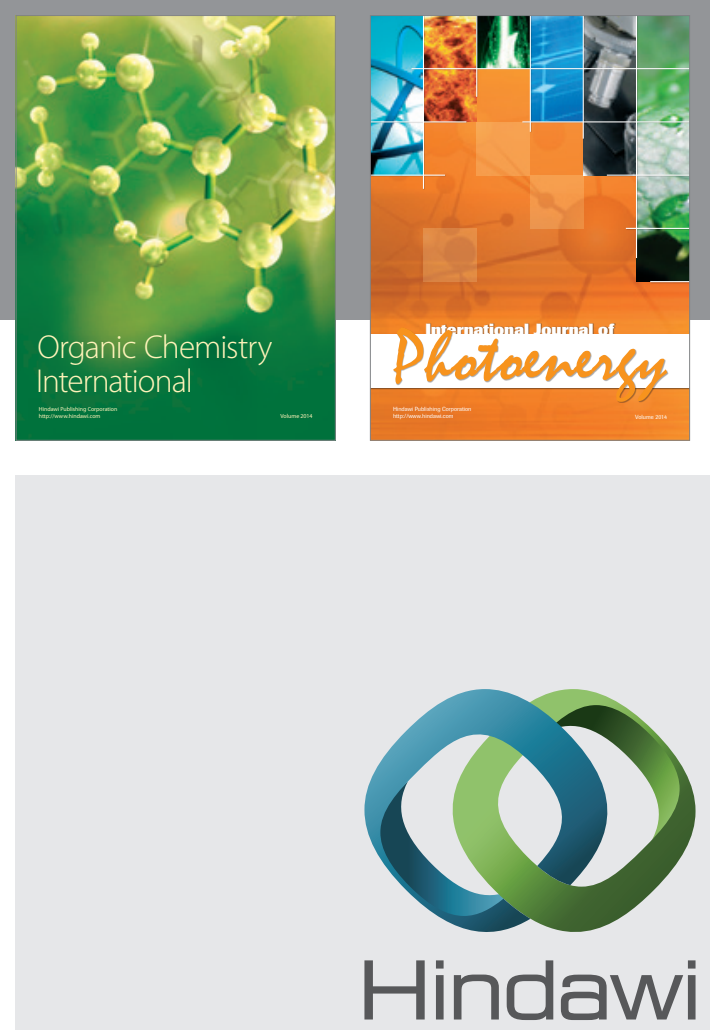

Submit your manuscripts at

http://www.hindawi.com
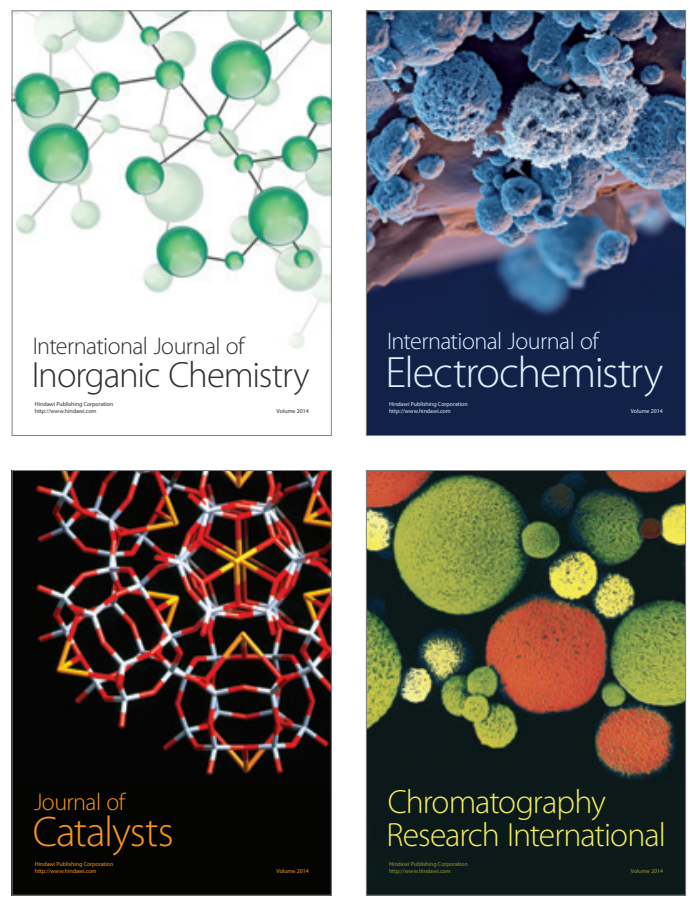
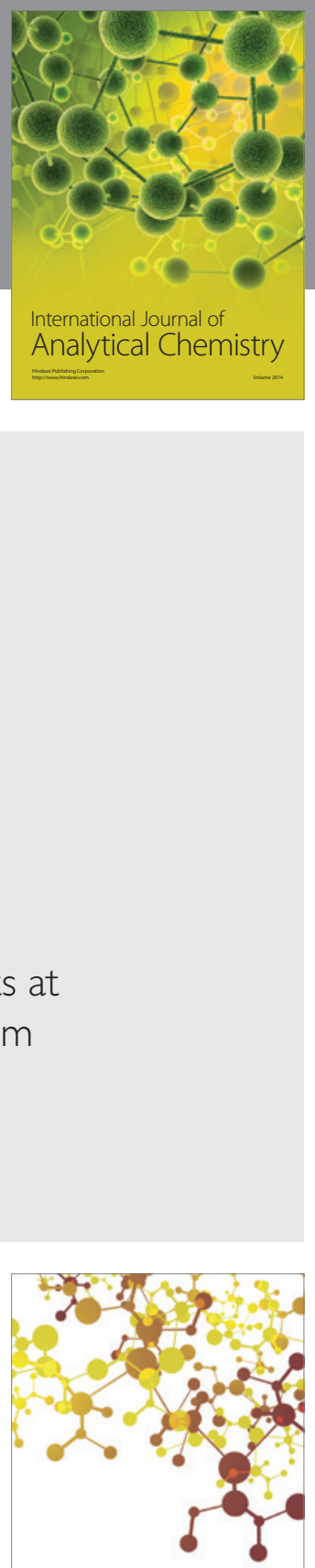

Journal of

Applied Chemistry
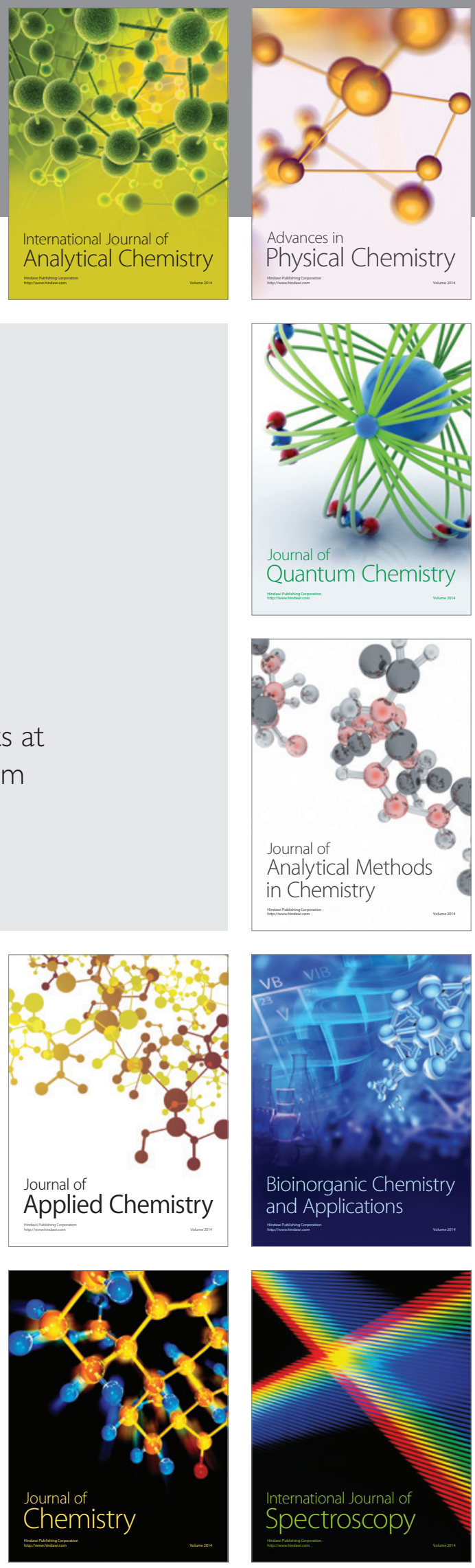